\title{
FIRST BRITISH MESOZOIC SPIDER, FROM CRETACEOUS AMBER OF THE ISLE OF WIGHT, SOUTHERN ENGLAND
}

\author{
by PAUL A. SELDEN
}

\begin{abstract}
Cretamygale chasei, a new genus and species of spider, is described from a single specimen preserved in amber of early Barremian age from the Isle of Wight. This is the oldest (and second Cretaceous) amber spider to be described, and the first record of a Mesozoic spider from Britain. It belongs to the group Bipectina of the infraorder Mygalomorphae, and is tentatively referred to the family Nemesiidae. It is the oldest bipectinate, extending the record by around $90 \mathrm{myr}$, the only known fossil nemesiid, and the second oldest fossil mygalomorph.
\end{abstract}

KEY WORDS: Arachnida, Araneae, Arthropoda, Barremian, Chelicerata, Mygalomorphae, Nemesiidae.

MESOzOIC mygalomorph spiders were first described by Eskov and Zonshtein (1990) from localities in Lower Cretaceous strata of Transbaikalia and Mongolia. The oldest mygalomorph, Rosamygale grauvogeli Selden and Gall, 1992 was described from Triassic rocks of north-east France. The supposed Palaeozoic mygalomorph Megarachne servinei Hünicken (1980) is doubtfully a spider (Eskov and Zonshtein 1990; José Corronca, pers. comm. 2001); Cenozoic mygalomorphs are known (reviewed in Eskov and Zonshtein 1990). There are a few records of Cretaceous spiders: indeterminate Araneae from the ?Barremian-Aptian of Koonwarra, South Australia (Jell and Duncan 1986); orbicularian araneomorphs from the Berriasian-Valanginian of the Sierra de Montsech, Spain (Selden 1989, 1990, 1991); an unnamed lycosoid from Orapa, Botswana ('early Upper Cretaceous'; Rayner and Dippenaar-Schoeman 1995), a poorly preserved specimen from the Albian of México (Feldmann et al. 1998), and many new spider specimens (including mygalomorphs) reported from the Aptian Crato Formation of Brazil, but only one (an araneomorph) has so far been described (Mesquita 1996). Spiders are known from Cretaceous amber from Canada (Campanian; McAlpine and Martin 1969), Siberia (Albian-Santonian; Eskov and Wunderlich 1994; Zherikhin and Eskov 1999), France (Cenomanian; Schlüter 1978), Lebanon (Aptian, possibly reworked Hauterivian; Schlee and Dietrich 1970; Azar 1998), Burma (reworked Cretaceous in Eocene sediments; Cockerell 1920; Rasnitsyn and Ross 2000; Zherikhin and Ross 2000), Caucasus (Cenomanian, Coniacian; Eskov and Wunderlich 1994), New Jersey (Turonian; Grimaldi et al. 2000), Álava, Spain (Albian-Aptian; Alonso et al. 2000) and Asturias, Spain (Arbizu et al. 1999) but only one specimen (Lagonomegops sukatchevae Eskov and Wunderlich, 1994) has been formally described from Cretaceous amber. Here, a new mygalomorph genus is described, from a single specimen preserved in amber of early Barremian age from the Isle of Wight. This is the oldest (and second Cretaceous) amber spider to be described, and the first record of a Mesozoic spider from Britain. The spider, described here as Cretamygale chasei gen. et sp. nov., has been figured in a popular book on amber (Ross 1998, fig. 30, and was also mentioned by Jarzembowski 1999). It belongs to the group Bipectina Goloboff, 1993 of the infraorder Mygalomorphae Pocock, 1892, and is tentatively referred to the family Nemesiidae Simon, 1889. It is the oldest bipectinate, extending the record by around $90 \mathrm{Ma}$, the only known fossil nemesiid, and the second oldest fossil mygalomorph. It is suggested that the Mygalomorphae had a worldwide distribution before the break-up of the Pangaean supercontinent. The occurrence of another member of a Recent spider family in rocks of Mesozoic age is further evidence of the antiquity of modern spider families. 


\section{STRATIGRAPHY AND PALAEOECOLOGY}

Stratigraphy. The specimen comes from lignitic marls between the Chilton Chine Sandstone and the Brighstone Sandstone, Wessex Formation, at beach level about $250 \mathrm{~m}$ south-east of the mouth of Chilton Chine, Brighstone Bay, Isle of Wight (Nicholas et al. 1993; Insole et al. 1998). Nicholas et al. (1993) described the locality and stratigraphy in detail. Amber occurs in two main lignite horizons, separated by about $10 \mathrm{~cm}$ of blue-grey clay and silt with large, lignitic logs. These horizons occur above a fining-upward sequence of marl conglomerate, the whole being within a sequence of grey or red marls. The age is Barremian (Hughes and McDougall 1990).

Palaeoecology. The plant debris amongst which the amber occurs is mostly fine twigs and smaller fragments, the whole being rather poorly sorted. Nicholas et al. (1993) concluded that the amber horizons represented forest floor litter that had been transported a short distance by river action. The presence of pyrite suggests that deposition occurred in an anoxic environment. The Wessex Formation consists of a series of fining-upwards sequences of conglomerates to mudstones, with an erosional base to each cycle, abundant plant debris, and considerable lateral variation. This suggests a geomorphological model of a perennial, moderately sized, high sinuosity river flowing over a low-relief alluvial plain (Insole and Hutt 1994). Infra-red absorption spectral analysis of the amber, together with evidence from the macroplant fossils, suggest the amber-producing tree belonged to the Coniferopsida: Araucariaceae, Cupressaceae, or Taxodiaceae, though these closely related, extant families may not have been distinguishable in the Early Cretaceous (Nicholas et al. 1993). The climate suggested for Early Cretaceous times in the Isle of Wight, based on palaeomagnetic and sedimentological evidence, was warm (mean annual temperature approximately $20-25^{\circ} \mathrm{C}$ ) with low, seasonal rainfall, commonly occurring as flash floods (Insole and Hutt 1994). These authors suggested that the local vegetation may have resembled savannah or chapparal.

\section{MATERIAL AND METHODS}

Preservation. The spider is preserved in clear, medium-coloured amber with a large number of tiny air bubbles and carbonized plant fragments. Adpressed against the spider, obscuring the anterior part of the sternum, is a piece of indeterminate arthropod cuticle. This is not part of the spider but could be the remains of prey. About half of the spider occurs in the amber, the remainder is missing (see below). The missing parts are: the frontal part of the left chelicera; all left legs and pedipalp, except the superior side of the pedipalp femur; the superior side of right leg 1 tarsus; the distalmost part of the tibia and all of the metatarsus and tarsus of right leg 2; the distal part of the tibia and all of the metatarsus and tarsus of right leg 3; most of the tibia and all of the metatarsus and tarsus, the inferior side of the coxa, trochanter, and proximal femur of right leg 4 ; the ventral part of the abdomen.

That part of the spider is missing may be due to erosion or preparation of the piece of amber, or that the spider was not entirely engulfed in amber and the missing parts decayed away. The abdomen and longer podomeres of the spider are deflated, as occurs rapidly in spiders after death due to dehydration. Since the spider is otherwise complete (apart from parts which are absent beyond the edge of the amber piece, see below), and the carapace is in place, presumably this is a dead spider rather than a moult. Furthermore, much of the specimen is covered, both internally and externally, with white or brown fuzz. The white fuzz was called 'emulsion' by Petrunkevitch (1942). The phenomenon is very common in Baltic amber. The emulsion is due to reaction of the amber-producing sap with moisture during early fossilization (Andrew Ross, pers. comm. 2001). However, in the Isle of Wight fossil it obscures some important details.

Methods. The specimen was studied, drawn and photographed under mineral oil, which enhances the clarity of the amber without chemical reaction. A Wild M7S stereomicroscope was used for the study, with a camera lucida tube for drawing and a Minolta Dynax 9 camera attached by means of a phototube for photomicrography. Because the specimen occurs at the corner of the piece of amber, better views of the spider cannot be obtained by grinding and polishing the specimen without also destroying much of it. 
Terminology and abbreviations. Macrosetae refer to large setae which thicken just distal to the base before tapering, unlike ordinary setae which do not; bristles resemble ordinary setae in shape but are as large as macrosetae. All three types occur on the legs of the fossil described here. Trichobothria are very long (more than the width of the podomere) hair-like structures which do not taper. They are recognizable in the fossil not only by their great length and consistent width but also because they are commonly bent (so were presumably less stiff than setae).

Abbreviations and conventions used in the text-figures. 1, 2, 3, 4 walking leg numbers; car, carapace; ch, chelicera; cx, coxa; fe, femur; ms, macroseta; mt, metatarsus; o t, ocular tubercle; op, opisthosoma; pa, patella; pd, pedipalp; st, sternum; ta, tarsus; ti, tibia; tr, trochanter; trich, trichobothrium. Shading marks areas of white (brown where marked) emulsion.

\section{SYSTEMATIC PALAEONTOLOGY \\ Order ARANEAE Clerck, 1757 \\ Suborder OPISTHOTHELAE Pocock, 1892 \\ Infraorder MYGALOMORPHAE Pocock, 1892}

Remarks. The orthognath chelicerae of Cretamygale refer this spider to either Mygalomorphae or the suborder Mesothelae Pocock, 1892. Cretamygale cannot be a mesothele because it lacks the mesothele synapomorphies of invaginated fourth coxae, tibial spurs, and deep and narrow sternum, and shows no opisthosomal tergites characteristic of these spiders. Araneomorphae Smith, 1902, the other infraorder in Opisthothelae, have labidognath chelicerae, so Cretamygale can also be excluded from this group. Other mygalomorph characteristics of Cretamygale include: relatively robust podomeres (slender in most araneomorphs); highly setose legs, with tarsal scopulae (less so in most araneomorphs); deep foveal pit with a pair of large, erect setae (common in mygalomorphs); and eyes clustered on a tubercle in an anteromedial position on the carapace.

\section{BIPECTINA Goloboff, 1993}

Remarks. Goloboff (1993) proposed the name Bipectina for his clade 68, which comprises Crassitarsae Raven, 1985 (re-delimited to include Microstigmatidae Roewer, 1942) + Rastelloidina Raven, 1985 + Diplurinae Simon, 1889. Put another way, this is the higher mygalomorphs: all families except Atypoidina Raven, 1985, Mecicobothriidae Holmberg, 1882, Hexathelidae Simon, 1892 and all Dipluridae Simon, 1889 except Diplurinae. The sister group to Bipectina lies within non-diplurine Dipluridae. Cretamygale can be referred to the Bipectina on the basis of a number of characters. Indeed, it is possible to identify the fossil with one of two groups within Bipectina: Diplurinae Simon, 1889 and Nemesiidae Simon, 1889, but whose relationships to each other and the remainder of Bipectina are unresolved. The characters used in this discussion are: eyes grouped on a tubercle situated anteromedially on the carapace; saddled cephalic area of carapace (caput), not strongly raised; sloping thoracic part of carapace; deep, transverse fovea; pair of large, erect setae on anterior wall of fovea; symmetrically arranged tarsal/metatarsal scopulae on leg 1 ; tarsus of leg 1 cracked ventrally; no claw tufts on leg 1.

Raven (1985) was the first to subject the infraorder Mygalomorphae to an extensive cladistic analysis. Later, Goloboff (1993) presented a reanalysis of the group, using computer parsimony programs. Comparing the few characters known for the fossil spider with the information in these two papers, in particular, it is possible to narrow down the identification of the fossil with some success. The ocular tubercle is widespread in mygalomorphs but is absent from Fornicephalae Raven, 1985 (= Atypoidina + Rastelloidina). Goloboff's (1993) reanalysis indicated that Fornicephalae was paraphyletic but confirmed Atypoidea and Rastelloidina (= Actinopodidae Simon, 1892; Ctenizidae Thorell, 1887; Cyrtaucheniidae Simon, 1889; Idiopidae Simon, 1889; Migidae Simon, 1889) separately as monophyletic groups. The same groups without an ocular tubercle have a flat (i.e. not sloping) thoracic region and a raised caput (except for Migidae). On the basis of these three characters, it is unlikely that Cretamygale belongs in Atypoidea or Rastelloidina. The absence of claw tufts rules out the Theraphosoidina Raven, 1985 (=Theraphosidae 
Thorell, 1869; Barychelidae Simon, 1889; and Paratropididae Simon, 1889) among remaining families, and the presence of scopulae on leg 1 enables Hexathelidae, Microstigmatidae, Mecicobothriidae and most Dipluridae to be rejected, whilst narrowing the choice down to Nemesiidae or the subfamily Diplurinae (Dipluridae). These two groups also share with Cretamygale the characters of equal-sized anterior and posterior legs; symmetrical scopulae; straight, transverse fovea (except Nemesia Audouin, 1826); and commonly show a pair of erect setae in the fovea as well as a row of erect setae behind the ocular tubercle. The inferiorly cracked tarsus occurs in females of a number of genera of nemesiids as well as diplurines (Raven 1985).

Goloboff (1993, p. 30) remarked that both Dipluridae and Nemesiidae are very likely to change in composition as more becomes known about these families; possibly Dipluridae could be restricted to Diplurinae, and Nemesiidae is in need of reassessment. Goloboff (1995) analysed the South American nemesiids and came to the conclusion that the family, as currently delimited, was paraphyletic. In Goloboff's (1993) analysis, diplurines were hypothesized as sister group to all other Bipectina (which includes nemesiids and most other mygalomorph families). Raven (1985, p. 51) discussed whether Dipluridae and Nemesiidae could be considered closely related but concluded that there were too many additional steps involved in this hypothesis; these steps involve characters which are not preserved in the fossil, so add little to this debate.

Family NEMESIIDAE Simon, 1889

Remarks. Cretamygale is tentatively referred to this family on the basis that nemesiids generally show a more raised, less hirsute, cephalic region of the carapace than diplurines, in which the thoracic region is commonly higher than the caput (Raven 1985).

Genus CRETAMYGALE gen. nov.

Derivation of name. After creta, Latin for chalk, and basis for the Cretaceous Period; and mygale, French (also obsolete genus name), a mygalomorph spider.

Type and only known species. Cretamygale chasei $\mathrm{sp}$. nov.

Diagnosis. Bipectinate (nemesiid?) mygalomorph with ocular tubercle, caput not strongly raised, sloping thoracic region, pair of erect setae on anterior wall of fovea; on at least leg 1, tarsus and metatarsus with symmetrically arranged scopulae, tarsus cracked ventrally, no claw tufts.

Cretamygale chase $\mathrm{sp}$. nov.

Text-figures $1-6$

1998 Ross, fig. 30

Derivation of name. After Nick Chase, the collector of the specimen.

Holotype and only known specimen. IWCMS.1994.101, female or juvenile specimen, in the collections of the Museum of Isle of Wight Geology, Sandown, Isle of Wight, UK.

Diagnosis. As for the genus.

Decription. [NB: few lengths are given because it is impossible to orientate the specimen and still see the structure for accurate measurement]. Female or juvenile. Carapace with cephalic region (in side view) not strongly raised (Text-fig. 5), slightly higher than thoracic region only just anterior to fovea, slightly saddled, sharply bevelled down to fovea; sloping thoracic region with less raised posterolateral areas, excavated medioposterior area; deep, transverse foveal pit with steep anterior wall, behind bevelled edge of cephalic region, with pair of large, erect setae at base; 


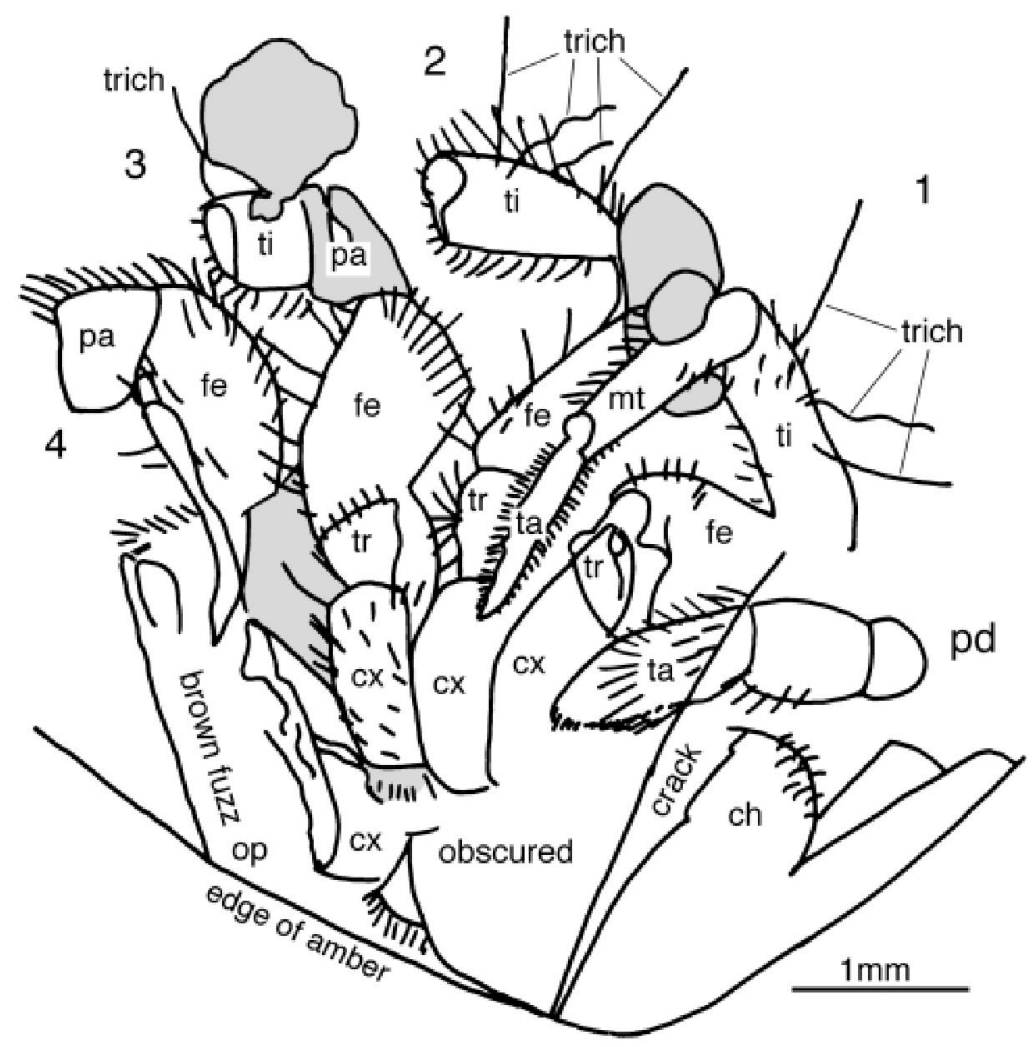

TEXT-FIG. 1. Camera lucida drawing of Cretamygale chasei sp. nov., holotype and only known specimen (IWCMS.1994.101). Anteroventral aspect, showing legs of right side of animal (anterior to the right). Note trichobothria and tarsal scopula (dense setation, diagrammatic).

single large, erect seta in posterior part of each posterolateral raised area of thoracic region; pair of erect setae situated anteromedially just in front of eye cluster, many other medium-sized, curved setae on carapace, especially behind eye cluster and in medioposterior excavated area of thoracic region, otherwise hirsute. Eyes clustered at anteromedial edge of carapace, on raised area (ocular tubercle). Only small part of posterior sternum visible, where produced between (at least) coxae 4 and coxae 3-4; surface covered with stout, curved setae; no sigilla in visible part of sternum.

All appendages covered with stout, curved setae. Chelicera not enlarged or porrect; medial face of chelicera flat; fang base anteroventral, fang horizontal; frontal part of chelicera with stout, downwardly curved setae. Pedipalp: coxae and trochanters not visible; femur with anterodistal macroseta; patella long, no macrosetae visible; tibia with at least four ventral macrosetae, three of which distal; tarsus thickened, scopulate ventrally and laterally, superior surface with numerous short, stiff macrosetae. Leg 1 tibia with at least four trichobothria in two rows on superior surface; metatarsus and tarsus slender, with scopulae of normal setae symmetrically arranged on inferior and lateral surfaces; metatarsus with at least three inferior macrosetae: one proximal and an apical pair; tarsus cut longitudinally by amber surface so that superior surface and terminal claws not preserved, no claw tufts, an inferior false articulation ('crack') occurs just distal to the half-way point of the tarsus. Leg 2 femur with at least two superior large bristles, also about three posteroventrally; tibia with at least one proximal and one medial ventral macrosetae, at least six trichobothria in two rows on superior surface, this podomere cut off at edge of amber piece. Leg 3 femur with at least three superior large bristles and about three posteroventrally; tibia mostly obscured by white emulsion and cut off at edge of amber. Leg 4 femur with superior and posteroventral large bristles; tibia cut off near base.

Opisthosoma: posterior half absent, anterior half deflated and mostly obscured with white and brown fuzz; no tergites visible; cuticle surface bears numerous stout, posteriorly curved setae. 

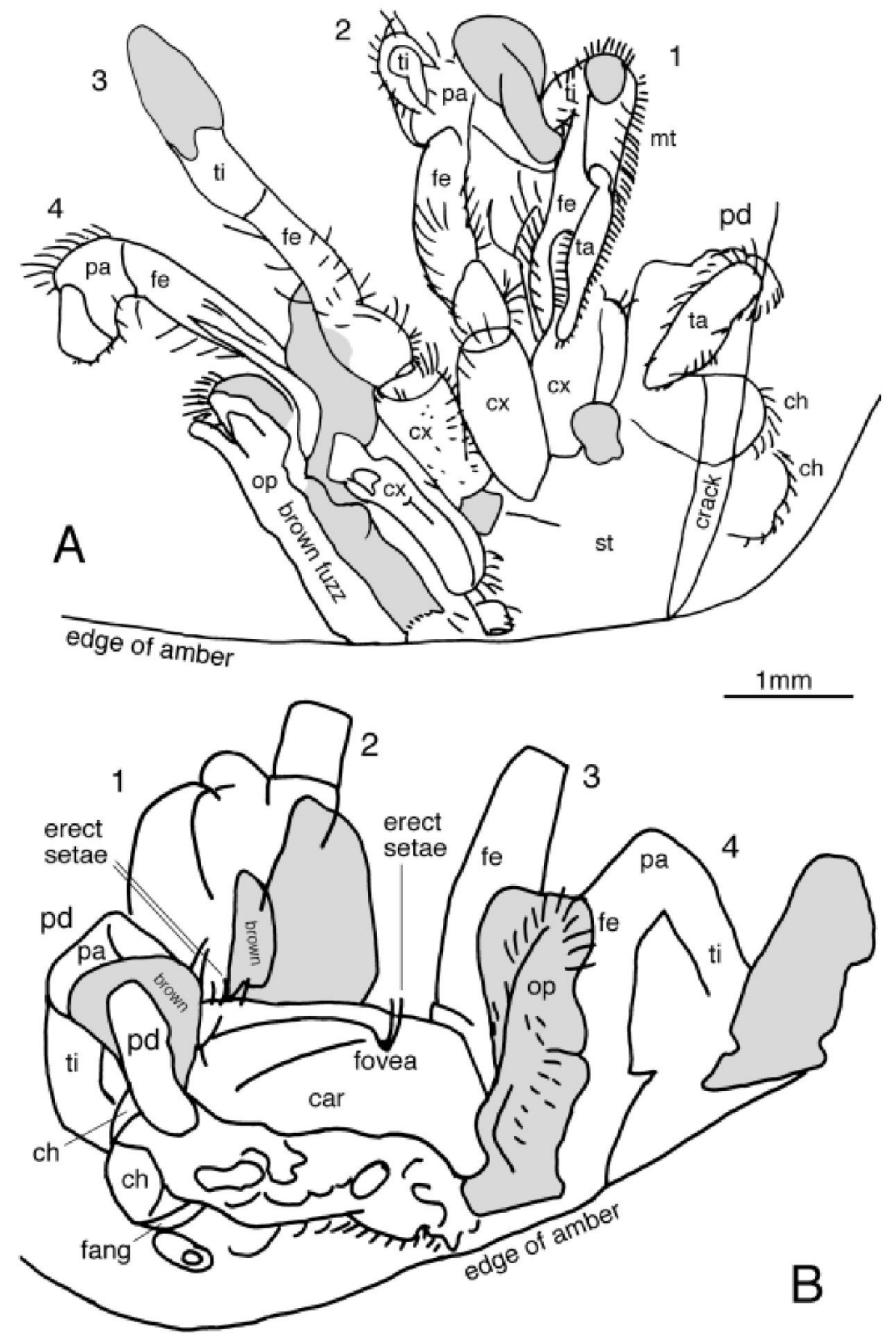

TEXT-FIG. 2. Camera lucida drawings of Cretamygale chasei sp. nov, holotype and only known specimen (IWCMS.1994.101). A, explanatory drawings for Text-figure 3, right ventrolateral aspect, anterior to right. B, explanatory drawing for Text-figure 4, left lateral aspect, anterior to left. Setae and scopulae diagrammatic.

\section{DISCUSSION}

The discovery of a member of the Bipectina in the Lower Cretaceous (Barremian, 121-127 Ma) pushes the age of this group back some 90 myr because the previously described earliest bipectinate mygalomorph is the diplurid Clostes priscus Menge, 1869 from Eocene (c. $35 \mathrm{Ma}$ ) Baltic amber (Petrunkevitch 1946). A 


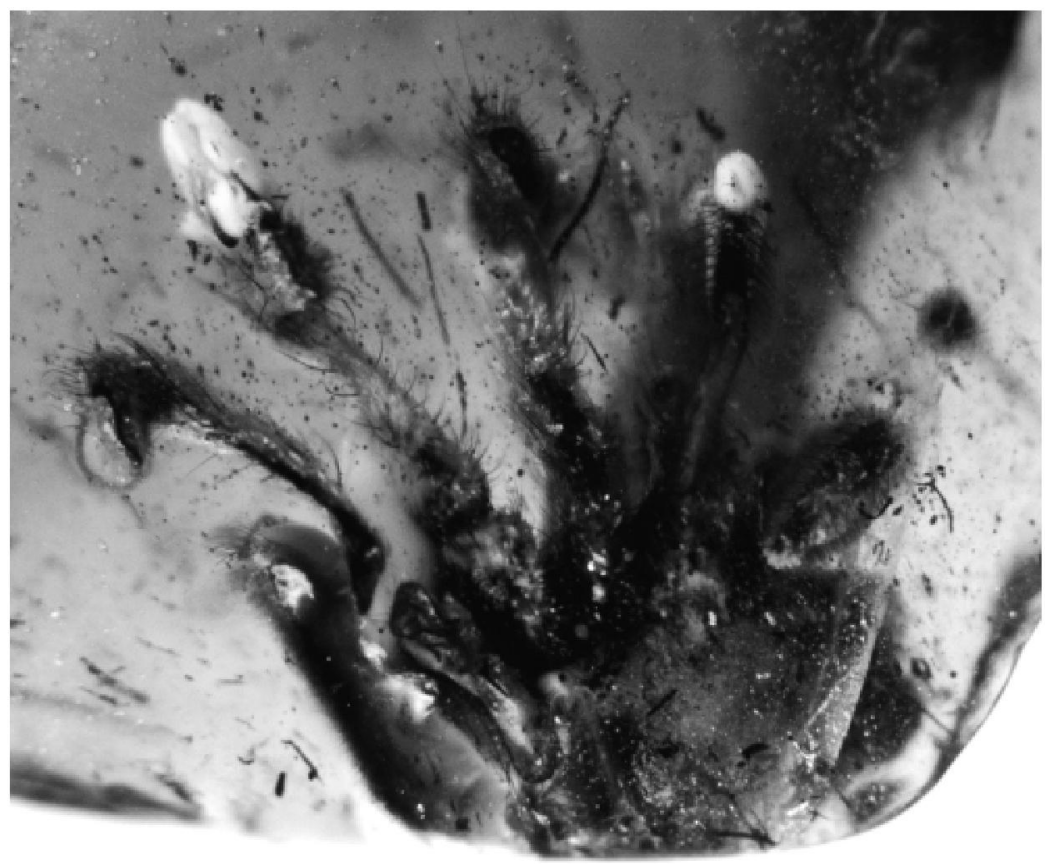

TEXT-FIG. 3. Cretamygale chasei sp. nov., holotype and only known specimen (IWCMS.1994.101), right ventrolateral aspect, anterior to right; $\times 15$.

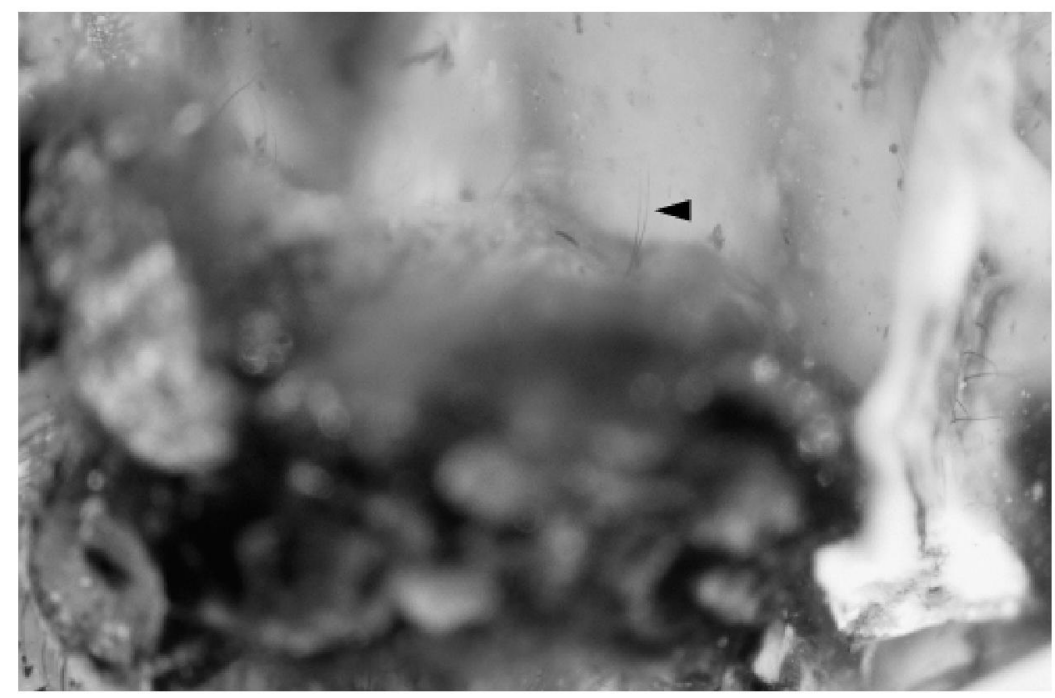

TEXT-FIG. 4. Cretamygale chasei sp. nov., holotype and only known specimen (IWCMS.1994.101), left lateral aspect, anterior to left, focused to show profile of carapace (see Text-figure 5), erect setae posterior to ocular tubercle, and pair of erect setae within fovea (arrowed); $\times 28$.

juvenile pycnotheline nemesiid reported from Dominican amber (Schawaller 1981) is considered to be a trichopelmatine (Wunderlich 1988), a subfamily in Theraphosidae (Raven 1994), and the referral of Eodiplurina cockerelli Petrunkevitch, 1922 from Tertiary strata of Florissant, Colorado to Nemesiidae 

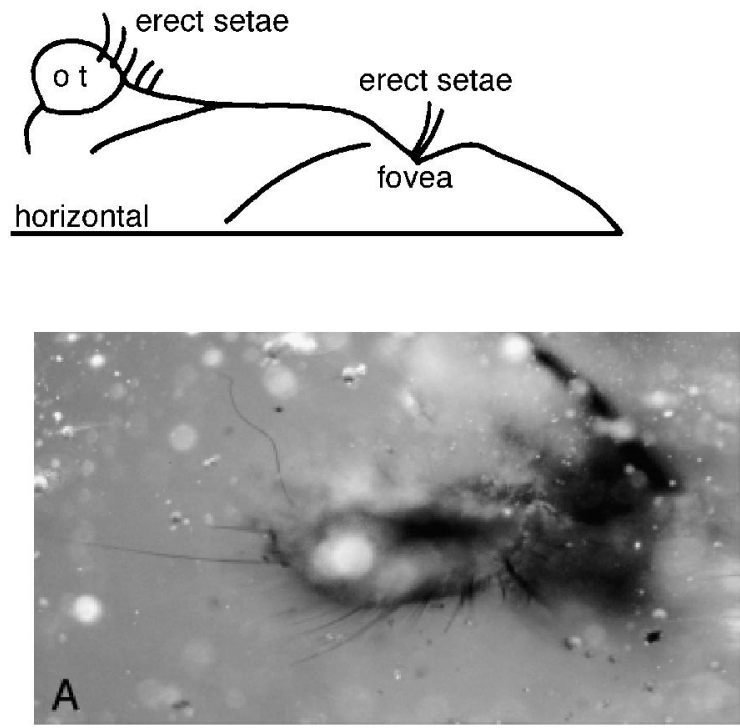

TEXT-FIG. 5. Diagrammatic left lateral view of carapace of Cretamygale chasei sp. nov., showing slope and elevation of cephalic (= caput, anterior to fovea) and thoracic (posterior to fovea) regions, erect setae, and ocular tubercle relative to suggested horizontal plane.

TEXT-FIG. 6. Cretamygale chasei sp. nov., holotype and only known specimen (IWCMS.1994.101). A, left leg 2 tibia, end-on view, with two trichobothria in focus, one straight and one sinuously bent, arising from superior surface (to left); $\times 20$. B, apex of metatarsus and tarsus of leg 1 , cut longitudinally in the horizontal plane by the amber surface, showing large, curved setae, macrosetae (one pair infero-apically on the metatarsus, out of the plane of focus), symmetrically arranged scopulae on lateral and inferior surfaces of tarsus, and inferior false articulation (arrowed); distal to right, anterior to top; $\times 20$.

(Eskov and Zonshtein 1990) is untenable because this genus has uniserially dentate tarsal claws; nemesiid claws are bipectinate. Therefore, Cretamygale is the only known fossil nemesiid. It is also the second oldest mygalomorph known, and only the fifth Mesozoic mygalomorph to be described; see Selden (1993, 1997) for fossil records of Mygalomorphae.

The oldest mygalomorph described is Rosamygale grauvogeli Selden and Gall (1992) from the Triassic (Anisian, 234-242 Ma) of France. This was placed in the modern family Hexathelidae, with some reservations. One character which showed little homoplasy in Goloboff's (1993) analysis is the presence of silk-producing spigots on the basal article of the posterior lateral spinnerets (PLS), a synapomorphy for Orthopalpae Raven, 1985 as redefined by Goloboff. Non-mygalomorphs, atypoids and mecicobothriids lack such spigots, whilst they occur in nearly all other mygalomorphs, including the relatively basal Hexathelidae. In connection with this, Goloboff (1993, p. 25) remarked 'Selden and Gall stated that the spigots "occur ... distally and laterally along the length of the PLS" (Selden and Gall, 1992: 228). If that means that the spigots were absent from the basal article of the PLS, the genus should be excluded from the Hexathelidae (and possibly from the Orthopalpae, as redefined below).' Indeed, spigots do occur along the whole length of the PLS, including the basal article, as can be seen in plate 5, figure 5, and plate 6, figure 2 of Selden and Gall (1992), thus providing additional evidence to the placement of this genus in Hexathelidae.

Eskov and Zonshtein (1990) described two monotypic genera of Mecicobothriidae (sister taxon to Orthopalpae), one species of Atypidae Thorel1, 1870, and one species of Antrodiaetidae Gertsch, 1940 (together = Atypoidina, sister taxon to Mecicobothriidae + Orthopalpae) from the Cretaceous (?Albian, 99-112 Ma) of Siberia and Central Mongolia. The presence of a nemesiid in the Early Cretaceous suggests a pre-Cretaceous origin for Bipectina (e.g. Dipluridae should also occur in rocks of this age). Eskov and Zonshtein (1990) proposed an 'Age of Mygalomorphs' in the late Early Cretaceous, during which time araneomorph spiders are supposed to have almost disappeared from the fossil record and a diverse fauna of primitive mygalomorphs (Atypidae, Mecicobothriidae) replaced them. This theory was based on the 
following observations. The occurrence of three Mesozoic mygalomorphs: one mecicobothriid from Transbaikalia and another, together with an antrodiaetid, from Mongolia. At the time of their publication, known Mesozoic araneomorphs comprised a few indeterminate and/or undescribed specimens from the Lower Cretaceous of Australia, Botswana and Spain, and two araneoids from the Jurassic of Asia (Eskov 1984, 1987); undescribed material from these Jurassic localities was also noted. As Eskov and Zonshtein (1990, p. 362) themselves pointed out, these data are scanty and their stratigraphical and geographical precision questionable. Nevertheless, they invoked the 'Cretaceous biocoenotic crisis' (Zherihkin 1978, and additional references in Eskov and Zonshtein 1990) to explain these data. Since 1990, the Mesozoic record of Araneae, particularly araneomorphs, has increased, and there are also many new specimens awaiting description from both amber and other sediments of Early Cretaceous age (see first paragraph of this paper). There were insufficient data in 1990 to draw any conclusions about Mesozoic spider diversity, and as more information becomes available the concept of an 'Age of Mygalomorphs' diminishes.

Mygalomorph spiders are mainly ground-dwellers, commonly living in burrows, or webs beneath logs or in litter. There is little evidence from the morphology of Cretamygale to suggest its mode of life. Mygalomorphs live mainly in tropical to subtropical climate regimes, from desert to rainforest habitats. Few occur in temperate or cooler climates (only one species, Atypus affinis Eichwald, 1830 occurs in Britain); thus the warm, dry climate suggested for the Wealden of the Isle of Wight would be eminently suitable for mygalomorphs. Nemesiids have a world-wide distribution between latitudes of about $45^{\circ}$ North and South today. They commonly construct burrows with or without a trap-door, though it is likely that Cretamygale either did not or was a wandering immature spider.

Acknowledgements. I thank Nick Chase, finder of this unique specimen, for kindly donating it to the Museum of Isle of Wight Geology, thus making it available for scientific study, and Steve Hutt and Martin Munt for the loan of the specimen. Thanks also go to Robert Raven (Queensland Museum) and Fred Coyle (Western Carolina University) for comments on mygalomorphs, Andrew Ross (The Natural History Museum, London) for information on amber, David Penney (University of Manchester) for comments on the draft of the paper, and Jason Dunlop (Humboldt University Museum, Berlin) and Robert Raven for helpful referees' comments.

\section{REFERENCES}

ALONSO, J., ARLllo, A., BARRón, E., CORRAL, J. C., GRIMALT, J., LóPEZ, J. F., LóPEZ, R., MARTíneZ-DELClos, X., ORTUÑo, V., PEÑAlVER, E. and TRINCÃO, P.R. 2000. A new fossil resin with biological inclusions in Lower Cretaceous deposits from Álava (northern Spain, Basque-Cantabrian Basin). Joumal of Paleontology, 74, 158-178.

ARBIZU, M., BERNÁRDEZ, E., PEÑAlVER, E. and PRIETO, M. A. 1999. El ámbar de Asturias. 245-254. In ALONSO, J., CORRAL, J. C., and LóPEZ, R. (eds.). Proceedings of the world congress on amber inclusions. Estudios del Museo de Ciencias Naturales de Álava, 14 (Número Especial 2). Álava, Spain, 272 pp.

AUdoun, J. V. 1826. Explication sommaire des planches d'arachnides de 1'Egypte et de la Syrie, publiées par Jules-César Savigny. 99-186. In: Description de l'Egypte. Atlas. Histoire Naturelle, volume 1, part 4, 9 pls.

AZAR, D. 1998. Lebanese lower Cretaceous amber: «An exceptional window to the past». [Poster abstract]. p. 139. World Congress on Amber Inclusions, 20-23 October 1998, Vitoria, Álava, Basque Country, Spain.

CLERCK, C. 1757. Araneae suecici, descriptionibus et figuris oeneis illustrati, ad genera subalterna redacti speciebus ultra LX determinati. Stockholm, 154 pp., 6 pls.

COCKERELL, T. D. A. 1920. Fossil arthropods in the British Museum: IV. Annals and Magazine of Natural History, Series 9, 6, 211-214.

EICHWALD, E. 1830. Zoologica specialis, quam expositis animalibus tum vivis, tum fossilibus potissimum Rossiae in universum et Poloniae in specie, in usum lectionum publicarum in universitate Caesarea Vilnensi habendarum edidit. Vilna, 1830-1831, pars altera 63-67.

ESKov, K. Y. 1984. A new fossil spider family from the Jurassic of Transbaikalia (Araneae: Chelicerata). Neues Jahrbuch für Geologie und Paläontologie, Monatshefte, 1984, 645-653.

1987. A new archaeid spider (Chelicerata: Araneae) from the Jurassic of Kazakhstan, with notes on the so-called

'Gondwanan' ranges of recent taxa. Neues Jahrbuch für Geologie und Paläontologie, Abhandlungen, 175, 81-106.

—_ and WunDERLICH, J. 1994. On the spiders from Taimyr ambers, Siberia, with the description of a new family and with general notes on the spiders from the Cretaceous resins. Beiträge zur Araneologie, 4, 95-107.

_ _ and zONSHTEIN, S. L. 1990. First Mesozoic mygalomorph spiders from the Lower Cretaceous of Siberia and 
Mongolia, with notes on the system and evolution of the order Mygalomorphae (Chelicerata: Araneae). Neues Jahrbuch für Geologie und Paläontologie, Abhandlungen, 178, 325-368.

FELDMANN, R.M., VEGA, F. J., APPLEGATE, S. P. and BISHOP, G. A. 1998. Early Cretaceous arthropods from the Tlayúa Formation at Tepexi de Rodríguez, Puebla, México. Journal of Paleontology, 72, 79-90.

GERTSCH, w. J. 1940. In COMSTOCK, J. H. The spider book. Revised and edited by Willis J. Gertsch. Doubleday and Co., Ithaca, New York, $729 \mathrm{pp}$.

GOLOBOFF, P.A. 1993. A reanalysis of mygalomorph spider families (Araneae). American Museum Novitates, 3056, $1-32$.

— 1995. A revision of the South American spiders of the family Nemesiidae (Araneae, Mygalomorphae). Part I: species from Peru, Chile, Argentina, and Uruguay. Bulletin of the American Museum of Natural History, 224, $1-189$.

GRIMALDI, D., SHEDRINSKY, A. and WAMPLER, T. 2000. A remarkable deposit of fossiliferous amber from the Upper Cretaceous (Turonian) of New Jersey, U.S.A. 1-76. In GRIMALDI, D. (ed.). Studies in fossil amber, with particular reference to the Cretaceous of New Jersey. Backhuys, Leiden.

HOLMBERG, E. L. 1882. Observations à propos de sous-ordre des araignées territelaires (Territelariae). Boletin de Academio Argentino, 4, 153-174.

HUGHES, N. F. and MCDOUGALL, A. B. 1990. New Wealden correlation for the Wessex Basin. Proceedings of the Geologists' Association, London, 100, 85-90.

HÜNICKEN, M. A. 1980. A giant fossil spider (Megarachne servinei) from Bajo de Véliz, Upper Carboniferous, Argentina. Boletin de la Academia Nacional de Ciencias, Córdoba, Argentina, 53, 317-341.

INSOLE, A. N. and HUTT, S. 1994. The palaeoecology of the dinosaurs of the Wessex Formation (Wealden Group, Early

Cretaceous), Isle of Wight, southern England. Zoological Journal of the Linnean Society, 112, 197-215.

DALEY, B. and GALE, A. 1998. The Isle of Wight. Geologists' Association Guide 60. The Geologists' Association, London, $132 \mathrm{pp}$.

JARZEMBOWSKI, E. A. 1999. British amber: a little-known resource. 133-140. In ALONSO, J., CORRAL, J. C., and LÓPEZ, R. (eds). Proceedings of the world congress on amber inclusions. Estudios del Museo de Ciencias Naturales de Álava, 14 (Número Especial 2). Álava, Spain. 272 pp.

JELL, P. A. and DUNCAN, P. M. 1986. Invertebrates, mainly insects, from the freshwater, Lower Cretaceous, Koonwarra

Fossil Bed (Korumburra Group), South Gippsland, Victoria. Memoirs of the Association of Australasian Palaeontologists, 3, 311-205.

MCALPINE, J. F. and MARTIN, J. E. 1969. Canadian amber - a paleontological treasure-chest. The Canadian Entomologist, 101, 819-838.

MENGE, A. 1869. Über einen Scorpion und zwei Spinnen im Bernstein. Schriften der Naturforschenden Gesellschaft in Danzig, Neue Folge, 2, 1-9.

MESQUITA, M. V. 1996. Cretaraneus martinsnetoi n. sp. (Araneoidea) da Formação Santana, Cretáceo Inferior da Bacia do Araripe. Revista Universidade Guarulhos, Série Geociências, 1, 24-31.

NICHOLAS, C. J., HENWOOD, A. A. and SIMPSON, M. 1993. A new discovery of early Cretaceous (Wealden) amber from the Isle of Wight. Geological Magazine, 130, 847-850.

PETRUNKEVITCH, A. 1922. Tertiary spiders and opilionids of North America. Transactions of the Connecticut Academy of Arts and Sciences, 25, 211-279.

- 1942. A study of amber spiders. Transactions of the Connecticut Academy of Arts and Sciences, 34, $119-464$.

- 1946. Fossil spiders in the collection of the American Museum of Natural History. American Museum Novitates, 1328, $1-36$.

POCOCK, R. I. 1892. Liphistius and its bearing upon the classification of spiders. Annals and Magazine of Natural History, Series 6, 10, 306-314.

RASNITSYN, A. P. and ROSS, A. J. 2000. A preliminary list of arthropod families present in the Burmese amber collection at The Natural History Museum, London. Bulletin of The Natural History Museum, London (Geology), 56, 21-24.

RAVEN, R. J. 1985. The spider infraorder Mygalomorphae (Araneae): cladistics and systematics. Bulletin of the American Museum of Natural History, 182, 1-180.

- 1994. Mygalomorph spiders of the Barychelidae in Australia and the western Pacific. Memoirs of the Queensland Museum, 35, 291-706.

RAYNER, R. J. and DIPPENAAR-SCHOEMAN, A. S. 1995. A fossil spider (superfamily Lycosoidea) from the Cretaceous of

Botswana. South African Journal of Science, 91, 98-100.

ROEWER, C. F. 1942. Katalog der Araneae. Volume 1. Bremen, $1040 \mathrm{pp}$.

Ross, A. J. 1998. Amber. The natural time capsule. The Natural History Museum, London, 73 pp. 
SCHAWALLER, w. 1981. Übersicht über Spinnen-Familien im Dominikanischen Bernstein und anderen tertiären Harzen

(Stuttgarter Bernsteinsammlung: Arachnida, Araneae). Stuttgarter Beiträge zur Naturkunde Serie B, 77, 1-10.

SCHLEE, D. and DIETRICH, H. G. 1970. Insektenfürender Bernstein aus der Unterkreide des Lebanon. Neues Jahrbuch für

Geologie und Paläontologie, Monatshefte, 1970, 40-50.

SCHLÜTER, T. 1978. Zur Systematik und Palökologie harzkonservierter Arthropoda einer Taphozönose aus dem

Cenomanium von NW-Frankreich. Berliner Geowissenschaftiche Abhandlungen (Series A), 9, 1-150.

SELDEN, P.A. 1989. Orb-web weaving spiders in the early Cretaceous. Nature, 340, 711-713.

1990. Lower Cretaceous spiders from the Sierra de Montsech, north-east Spain. Palaeontology, 33, 257-285.

1991. Lower Cretaceous spiders from the Serra del Montsec (Spain). 53-58. In MARTínEZ-DELCLòs, X. (ed.). The

Lower Cretaceous lithographic limestones of Montsec. Ten years of paleontological expeditions. Institut d'Estudis

Ilerdencs, Lleida, Spain, $106 \mathrm{pp}$.

1993. Arthropoda (Aglaspidida, Pycnogonida and Chelicerata). 297-320. In BENTON, M. J. (ed.). The fossil record

2. Chapman \& Hall, London, xvii $+845 \mathrm{pp}$.

1997. La historia geologica de las Arañas (Araneae). In MELIC, A. (ed.). PaleoEntomología, Volumen

Monográfico, Boletin de la Sociedad Entomologica Aragonesa 16, 105-112.

—_ and GALL, J.C. 1992. A Triassic mygalomorph spider from the northern Vosges, France. Palaeontology, 35,

$211-235$.

SIMON, E. 1889. Voyage de M. E. Simon au Venezuela (décembre 1887-avril 1888). 4e mémoire. Arachnides. Annales

de la Société Entomologique de France, Series 6, 9, 169-220, pls 1-3.

— 1892. Histoire naturelle des araignées. Second edition, volume 1, part 1. Encyclopédie Roret, Paris, 256 pp.

SMITH, F. P. 1902. The spiders of Epping Forest. Essex Naturalist, 12, 181-201.

THORELL, T. 1869. On European spiders. Nova Acta Regiae Societatis Scientarium Upsaliensis, Series 3, 7, 1-108.

- 1870. On European spiders. Nova Acta Regiae Societatis Scientarium Upsaliensis, Series 3, 7, 109-242.

1887. Viaggio di L. Fea in Birmania e regioni vicine. II. Primo saggio sui ragni birmani. Annali del Museo Civico

di Storia Naturale Giacomo Doria di Genova, Series 2, 8, 5-417.

WUNDERLICH, J. 1988. Die fossilen Spinnen im Dominikanischen Bernstein. Beiträge zur Araneologie, 2, 378 pp.

ZHERIKHIN, v. Z. 1978. Development and change of Cretaceous and Cenozoic faunistical complexes (Tracheata and

Chelicerata). Proceedings of the Paleontological Institute of the USSR Academy of Sciences, 165, 1-197. [In

Russian].

— and ESKOV, K. Y. 1999. Mesozoic and Lower Tertiary resins in former USSR. 119-131. In ALONSO, J., CORRAL, J. C.

and LÓPEZ, R. (eds). Proceedings of the world congress on amber inclusions. Estudios del Museo de Ciencias

Naturales de Álava, 14 (Número Especial 2). Álava, Spain, 272 pp.

- and Ross, A. J. 2000. A review of the history, geology and age of Burmese amber (Burmite). Bulletin of the

Natural History Museum, London (Geology), 56, 3-10.

Typescript received 18 May 2001

Revised typescript received 26 September 2001
PAUL A. SELDEN

Department of Earth Sciences University of Manchester

Manchester M13 9PL, UK e-mail Paul.Selden@man.ac.uk 